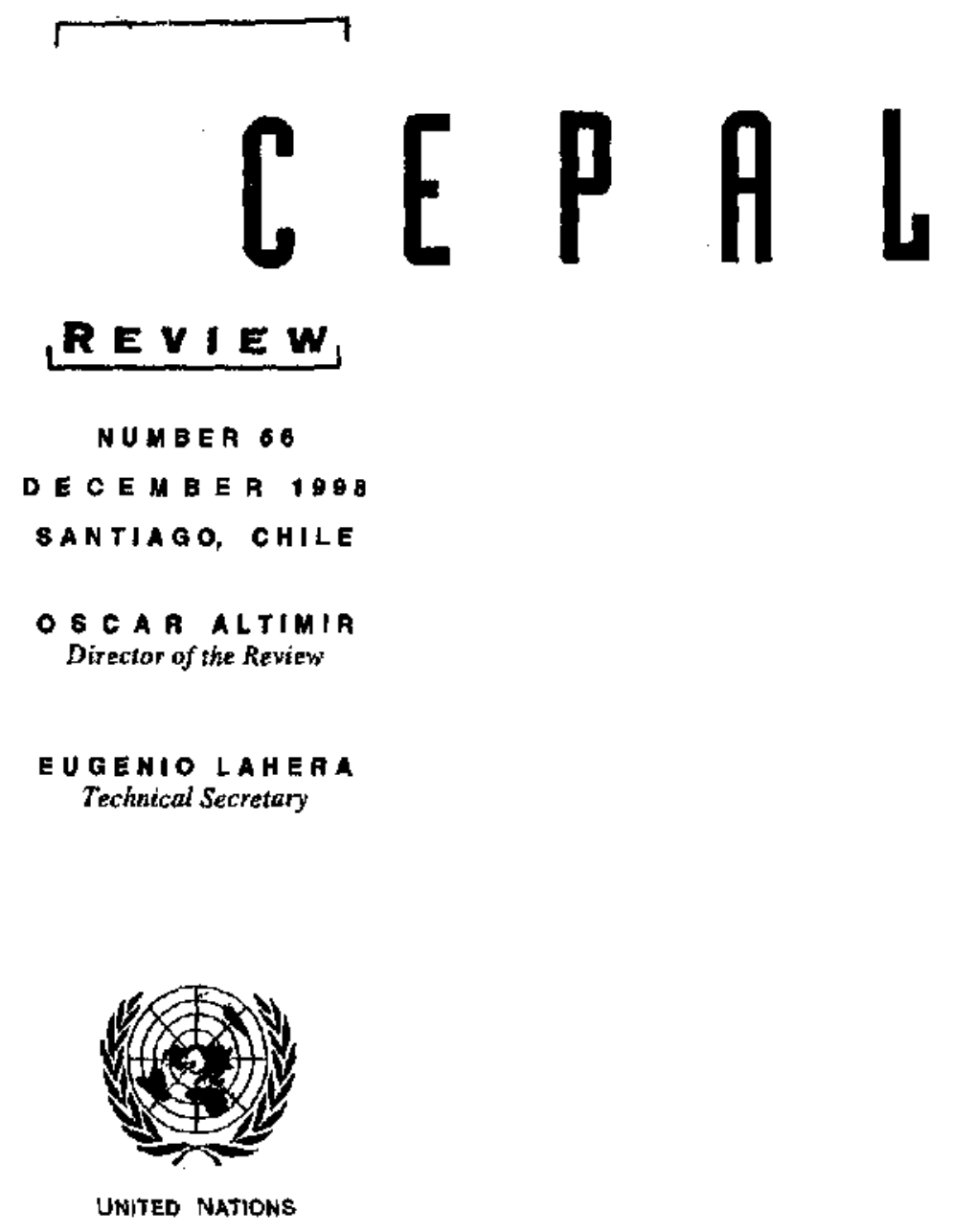


CONTENTS

Beyond the Washington Consensus: an ECLAC perspectlve

José Antonio Ocampo

The Cuban economy

David Ibarra and Jorge Máttar

Education in Latin America: demand and distribution are factors that matter

Nancy Birdsall, Juan Luis Londoño and Lesley O'Connell

Determinants of inequality among urban households

Luis Felipe Jiménez $L$, and Nora Ruedi $A$.

Health management contracts in Costa Alca from a comparative perspective

Ana Sojo

A development strategy tounded on natural resource-based production clusters

Jaseph Ramos

Blg Latin American industrial companies and groups

Celso Garrido and Wilson Peres

Between political control and efflciency gains:

the evolution of agrarian property rights in Mexico

Gustavo Gordillo, Alain de Janvry and Elizabeth Sadoulet

Tariffs and the Plano Real in Brazil

Renaso Baumann, Josefina Rivero and Yohana Zavattiero 


\section{Between political control and efficiency gains: the evolution of agrarian property rights in Mexico}

\section{Gustavo Gordillo}

United Nations Food and Agriculture Organization (FAO),

Rome.

\section{Alain de Janrry and Elleabeth Sadoulet University of California at Berkeley.}

As a product of the Mexican revolution, the ejido was originally organized as an institution with the multiple aims of achieving political control over the peasantry, representing peasants in their relations with the State, and assisting production by smallholders. These multiple objectives, which were initially consistent and supported a successful phase of growth and improved welfare, became increasingly contradictory, precipitating a major crisis in both production and rural welfare. By 1992, when Article 27 of the 1917 Constitution was reformed, the ejido was characterized by strong State intervention in the internal life of the ejido, including its decision-making mechanisms, the conditions for access to public resources, and the management of rural welfare. It was this very decay of the ejido system in a global context of political and economic liberalization that induced the profound reforms initiated under President Salinas, which include a redefinition of the relations between the State and households in the ejido sector, a change in the public institutions serving the sector, a reform of the legal framework that regulates access to land, and a modification in the instruments of agricultural policy. This article describes the initial impact of these reforms on the ejido sector. 
I

\section{The peasantry considered legally as minors: the conflict of rights, 1910-1940 ${ }^{1}$}

The social pact which guaranteed stability and peace in the countryside for much of the second half of this century and made it possible to institutionalize the conflicts which had arisen culminated its development during the regime of President Cárdenas, ${ }^{2}$ which came after 25 years of armed revolution, in the course of which the peasant revolt was militarily defeated, its political programme and social demands were incorporated into the constitutional framework of the new regime, its leaders were subjected to repression or were integrated into the political system, the other powers challenging State hegemony in the rural sector -the big landowners and the clergy- were politically split up, and the new institutional system was consolidated on the basis of corporative complementarity between the State agencies and the national farmers' organizations.

The basic provisions incorporated in article 27 of the Constitution were drafted in line with the views of a wide-ranging intellectual movement which exercised a great deal of influence over the vision of the new political regime and had already begun to express itself in the final days of the Porfirio Diaz dictatorship. ${ }^{3}$ One of the central points of this movement was its challenge to the conservative role played by the hacienda ${ }^{4}$ The reform of land distribution was viewed mainly as a policy for modernization, with the main task of removing constraints preventing the development of capitalism and the strengthening of the domestic market. It was therefore considered that land distribution reform would

$\square$ This article corresponds to a paper prepared for presentation at the 23rd International Conference of Agricultural Economists, Sacramento, California, August 1997.

1 This section is based on Gordillo (1988b).

2 President Lazaro Cárdenas governed Mexico from 1934 to 1940. For a thorough account of that period, see Cordova, 1973.

${ }^{3}$ This intellectual movement has been analysed by Krauze, 1971, and Cordova, 1973. One of the main representatives of this movement was Andrés Molina Enríquez.

${ }^{4}$ For the main arguments on the conservative role of the baciendas in Mexico, see Orozco, 1895. of itself create a social class capable of attaining the golden prize of modenity: the entrepreneurial fanner.

Perhaps the most important aspect of the views of this inteliectual movement was the emphasis placed on the role of the State as the social actor par excellence, both for politically reorganizing Mexican society and for promoting its economic development. Article 27 of the Constitution which emerged from the 1917 Constituent Congress established the State as the creator of property -thus going against the conventional doctrine of natural law- in the sense that it laid down that the rights of ownership of land and water belong originally to the Nation, which "has had and has the right of transferring their control to private individuals, thus giving rise to private property", and that "the nation shall always have the right to impose on private property restrictions in the public interest".

Even though the Constitution provides that the State is at all times the representative of the Nation, in practice by setting up a presidential regime it transferred to the Executive the representation of the nation and thus the role of creator of private property.

Article 27 recognized three forms of rural property ownership: small private property, communal property and ejido property, with differential treatment for ejido and communal property. Rightly noting the damage caused during the period of liberal reform in the latter half of the nineteenth century to the indigenous communities by the application of the concept that all citizens have equal legal capacity, it attempted to indemnify them by providing that all matters relating to land distribution or restitution or the settlement of disputes with the indigenous peoples should be solved in administrative courts and not the conventional judicial courts "so that they could act at their discretion, appraising the special circumstances that might arise as a result of the lack of capacity of the indigenous peoples. Otherwise, the administrative courts, which are administrative because they have to have discretionary powers, would be reduced by one or other legal means to becoming courts of law in the strict sense of the term, making 
them useless [for the purpose of land distribution]. It may be said that under those conditions no tand allocation or restitution can take place because it will be blocked and defeated by the skill and the resources of the landowner" (Garcia Trevifo, 1956, p. 51). Furthermore, in order that there should be no doubt on this differential treatment between the ejido and the community on the one side and private property on the other, Andres Molina Enríquez, the father of Mexican agrarian reform, argued several years later that "the distinguished members of the Querétaro Constituent Assembly bore in mind that both the communities themselves, in order to challenge the large landowners, and the labourers, in order to challenge the industrial entrepreneurs, were in such an inferior condition that it was indispensable for the government to act on their behalf in order to balance the forces on both sides and ensure full justice, playing the same role in both cases as a public prosecutor or state attorney in all matters in which minors are parties to the dispute". 5 This creates a "tutelage" relationship between the State and the peasants, who are considered to have a similar legal status to children or minors.

Without challenging the basic principle underlying the constitutional rules referring to the tutelage role of the State in respect of the peasants, the Cardenista school of thought introduced two major changes into government policy: the role of agrarian reform as an instrument of social stability, and the role of the ejido as a permanent institution. This policy was based on two assumptions: that it was no longer possible to delay resolving the basic demand of the peasant movement -namely, access to landbecause of the risk that the mass movement might spill over beyond the institutional framework, ${ }^{6}$ and secondly, that the ejido must become the hub of government rural policy. ${ }^{\text {? }}$

The ejido, which until then had been seen as an instrument for containing the demands of the peasant masses, took on new features (which were to be maintained until 1991), ${ }^{8}$ as the result of a two-fold

\footnotetext{
${ }^{5}$ Cited in Cordova, 1974, pp. 339-340.

${ }^{6}$ Indeed, many regional peasant leagues were accusing the new governing elite of betraying the main goals of the Mexican revoJution.

${ }^{7}$ Castillo, 1956, pp. 5-164, provides a pioneering interpretation of the problem of the Mexican ejido.

8 The constitutional reform of article 27 and the New Agrarian Law were passed through Congress and promulgated between November 1991 and February 1992 under President Salinas.
}

linkage: between the ejido and the State (and more particularly with government agencies), and between the ejido and its members, the ejidatarios, who are the partners in that production unit.

For the Cárdenas regime, the ejido was required to play a two-fold economic task: to supply cheap food and raw materials, and to boost the domestic market through the demand generated by the landowning peasants themselves. But for Cardenism these economic functions could only be properly performed if the ejido was linked to the government agencies. Consequently, a wide-ranging multi-tiered pyramidal arrangement was set up, linking the ejido through its managenent -the ejido Executive Committees and the Supervisory Council-9 with agrarian leagues and through them to the national-level Confederación Nacional Campesina (CNC) (National Peasant Confederation).

Even though the final phase of this organizational process culminated with a Presidential decree setting up the $\mathrm{CNC}$ and making it compulsory for all ejido members to belong to this organization, it would nevertheless be wrong to attribute its formation exclusively to a government decision. Before the foundation of the CNC there was a long period of peasant protests and organizational experiments on a regional basis which frequently led to the formation of state agrarian leagues and supraregional peasant representation bodies, such as the Liga Nacional Campesina (National Peasant League) ruled by Ursulo Galván from Veracruz in the early 1930s. Consequently, in the formation of the CNC the pressure from below stemming from the peasant protests converged with the central government's decision to consolidate its hegemony in the rural sector.

State tutelage over the peasants was not exhausted with the formation of the CNC, however. On the contrary, that body was only one of a number of institutions set up or strengthened during the Cárdenas regime with the express intention of supporting the development of the ejido and guaranteeing State hegemony. The agrarian law reforms in 1934 and 1935 gave the Agrarian Reform Department (Departamento de Asuntos Agrarios y Colonización) an enormous range of discretionary powers to protect and supervise the development of the ejidos and the communities, and above all to regulate access to the land. The formation of collective ejidos in the

\footnotetext{
${ }^{9}$ These issues are discussed at length in Gordillo, 1998b
} 
irrigated areas that had been expropriated from the large estate owners gave rise to a number of govern ment rural development agencies, of which the most important was the Banco Nacional de Credito Ejidal (the National Ejido Credit Bank). Although these institutions were very frequently referred to as being created to support and serve the ejido until it was wholly sustainable, both in practice and in the eyes and intentions of the political managers of these bodies the aim was to maintain permanent governmental intervention in the production, regulation and supply of agricultural output, particularly of the staple commodities.

Among all these institutions linked to the countryside, an initial division of labour very quickly took place: the CNC was responsible for channelling the peasant demands, particularly for land allocation, while the government agencies were responsible for regulating and settling those demands, particularly those relating to the organization of ejido production.

As already noted, the policies which eventually fashioned Mexican agrarian law therefore shared two ideas: that the State must protect the interests of the peasants as a means of guaranteeing social equilibrium, and that this protection or tutelage should be only temporary.

The solution to the dilemma raised by the practice of treating the peasantry as legal minors, which became necessary at the end of the 1940s when the institutionalization of the Mexican Revolution took place, was a hybrid formula first set out in the Bill tabled by President Calles in 1925, but whose most clear-sighted exponent was a former member of the Zapata army. It may be summarized as a combination of common property with private appropriation (usus fructus). ${ }^{10}$ The argument of the Zapatista Soto $y$ Gama was as follows: "Property belongs in common to the community. Why? Because it is the community which is entitled to dispose of a plot of land when, for example, the ejido member dies. Why? Because the community has the right to impose regulations on this ownership, or rather on its use. Usufruct is therefore private, because the plot is given so that all of its products can be enjoyed, the whole of its harvest, by the person receiving it. But is this private property viewed under Roman law, property typical of the capitalist? Obviously not. Can he dispose of that plot of land? No. Can he mortgage it? No. Neither can he

${ }^{10}$ This expression comes from Cordova, 1974, p. 339 alienate it or break it up. In other words be does not possess the third of the characteristic rights of the full notion of ownership: he has right of use, right to the fruits, right to usufruct or beneficial use (usus fructus) but no more than that. He does not have the right to dispose or misuse. He receives the land as a social function but does not have the right to abuse it. And the worst abuse that one can inflict on the land is not to work it" (Cordova, 1974, pp. 339-340).

The more moderate school of thought retained the ideal of private property as the final outcome of the ejido, and in order to make this happen some of the land allotted to the ejidos was split up into parcels, which originally should have not more than twenty hectares. In keeping with the ideas of the more radical school, an important role continued to be assigned to communal traditions, and thus a key component of each ejido was to be its communal area. Most importantly, however, the strategic vision that finally prevailed in the next three decades was the moderate one which saw agrarian reform and the ejido system basically as a political mechanism to ensure stability in the countryside. The role of the ejido as a production unit was completely neglected, and the function of supplying food was to be given to private agriculture.

However, this hybrid formula bears within it a two-fold contradiction which was to emerge constantly and which to a very large extent has created the conditions for today's peasant unrest. On the one hand, there is a contradiction with regard to the right of ownership which may be described in the following terms: the right to private enjoyment may mean -and this is what it has in fact meant- a growing erosion of common ownership to the extent that it gives certain members of the ejido community greater access to the economic and political resources which enable them to develop private capital accumulation processes. But in the same way the right to common ownership may mean -and has meant in reality - that private enjoyment may be prevented due to social inertia which immobilizes the production potential of all the commonly owned land.11

Furthermore, there is a second contradiction between the right of ownership and the right of farmers to organize themselves (Castillo, 1956). In the final

\footnotetext{
11 This contradiction regarding common lands is worthy of special attention because $67 \%$ of all the land distributed to the ejidos is common land. See de Janvry, Gordillo and Sacoulet. 1997.
} 
analysis, the legal ownership of the land is deposited in the State as the representative of the nation. But in the presidential system it is deposited in the President. This is further strengthened by a wide range of government agencies which intervene in the ejido production cycle. To the extent that this has weakened the ejido as a body of representation, it has mutilated or eroded the capacities of the rural communities to organize themselves to protect their own interests.

Both these contradictions have affected the internal operation of the ejido and particularly what we might call its polyarchic system. From the very beginning, two joint decision-making bodies were established: the Ejido Executive Committee, made up of a president, a secretary, a treasurer and three committee members, together with a Supervisory Council also made up of six people, but also the Ejido General Assembly, which was to meet at least once a month in order to define the general policies of the ejido and resolve internal disputes. The democratic principle of minorities and majorities was established and (until the statutory reforms in 1983) the Supervisory Council was antomatically made up of candidates from the electoral list which came second in the Ejido Executive Committee elections. Direct and universal suffrage was instituted, so that the elections to appoint the leadership were based on a list of ejido members with full rights (the electoral register) and the voting was direct, secret and personal. Rules of procedure were also drawn up to codify the procedures to be followed in decision-making and implementation and in the application of penalties, the sharing of profits, etc. The ejido leaders could stand for re-election, but they must receive the votes of three-quarters of the ejido members in order to be elected for a second term immediately following their period of office.

All these rights and powers which enabled the ejido members to organize themselves freely, making the ejido an organ which directly represented the peasants, were severely distorted by the dual contradiction embedded in the hybrid formula that was finally imposed, however.

To put it another way, as a body representing the peasants, the ejido is bound to be in a permanent state of tension with the ejido's quality of also being a State apparatus. This inevitable tension was expressed in the elective structure which determined the way in which the conflicts and struggles in the countryside were to be expressed. ${ }^{12}$ As a result of these struggles, the role of the ejido was strengthened both as an organ representing the peasants and as a State apparatus, but neither of these two aspects disappeared completely until the 1991 changes in article 27 of the Constitution.

\section{II}

\section{Loyalties and free-rlders (1940-1970)}

In the years following the Cárdenas regime, a development model became established which encouraged a rapid process of industrialization, exploiting the situation that had been created in the wake of the Second World War. The typical conflict between the agricultural and agro-exporting elites and the newly emerging industrial elites which blocked agrarian reform efforts in other Latin American countries emerged in Mexico only after the bulk of land reform had already occurred. Thus, the strategy of "no expropriation provided there is modernization", ${ }^{13}$ which was so successful in the 1960s and 1970s in the rest of Latin America, took a slightly different form in Mexico in the 1940s. In the political arrangernent reached in the second half of the 1940s between the various dominant elites, commercial private agriculture was given the main responsibility of supplying food to the urban centres whose growth was obviously being spurred by the incipient industrialization process. But the ejido agriculture -that is to say, the reformed sector-was there to stay, however precarious its existence was to be in the years to come. Under these assumptions -especially the irreversibility of land reform, albeit in fact blocked from

\footnotetext{
12 See Prseworski, 1985, especially p. 73: "The assertion that social relations structure class struggles must not be interpreted in a mechanical fashion. Social relations ... are a structure of choices given at a particular moment of history".

${ }^{13}$ See de Ianvry and Sadouled, 1989.
} 
then on- the "no expropriation if modernization" strategy functioned as elsewhere by "inducing the State to reallocate the land reform budget and redirect the attention of land reform agencies to the pursuit of modernization in medium and large farms" (de Janvry and Sadoulet, 1989, p. 1406).

\section{Survival and transformation}

Perhaps one of the most fascinating features that is noted when analysing this period has to do with the survival of the ejido itself. Why was it that -if the ejido, which had become a pool of cheap labour, was exploited and systematically decapitalized without bringing any real benefits to its members- the ejido members themselves did not give rise to an internal movement contesting the very concept of the ejido? And if the government was promoting different measures that tended to disintegrate the ejido and give pride of place to private farm ownership, why was it that it did not complete its work in this respect?

This second question could be answered pragmatically, by asserting that the State did not completely destroy the ejido system because it worked extremely well in the current circumstances, both for the purposes of rural accumulation and political control. But this is an ex post response to an ex ante phenomenon. Unless the State is viewed as an entity endowed with absolute rationality, this response takes no account of the reasons why, when faced with the unstoppable wave of rejection of populist policies which invaded the top levels of government from the late 1940s up to 1970 , decisions were not taken to end the transitional period that the existence of the ejido presupposed. ${ }^{14}$

As far as the first question is concerned, the answer might be that this did not happen because of the institutional barriers to changing the legal system without losing access to the land. But this decision by the ejido members not to abandon the ejido must be qualified, depending on what we mean by "abandon". Secondly, we must take account of the other key element which Hirschman (1977, pp. 78-104) introduces, namely loyalty -present and past- as a mechanism which strengthens continued membership of organizations under certain circumstances.

14 A well-documented study on this wave of rejection of populist policies is given in Torres and Medina, 1978, 1979 and $1979 \mathrm{~b}$, passim.
Abandoning the ejido, in the strict sense of the term, would have meant giving up the ejido parcel land and, more broadly speaking, losing membership in the ejido. In the period in question there were a number of circumstances which would have made this attractive, such as the higher wages that could be earned in more dynamic agricultural regions or in the cities, or emigration to the United States. Furthermore, in many rural areas of Mexico the emergence and consolidation of petty caciques or local bosses which occurred in this period generated forms of coexistence which were so unpleasant that this alone would probably have been enough to offset the uncertainties of moving to another rural area or to the large towns. This is not to say that this did not occur. Both in the more dynamic poles of agriculture and in the large urban centres there is strong evidence of migration flows from the ejidos during those years. ${ }^{15}$ But this migration, when it became permanent, usually meant the migration of a part of the household, but not of the member of the family in whom the agrarian rights in the ejido were vested (or when it did include him, he had already negotiated an agreement with the ejido authorities which generally implied leasing or lending his parcel for a period of time without losing it altogether). Thus, these migrations did not lead to a break with the ejido. It may be assumed that this was so because this first generation of ejido members were in a similar situation to that described by Hirschman: expensive entry into the organization, blind loyalty, and institutional barriers to leaving (Hirschman, 1977). The cost of entry was high because usually most of the ejido members had been struggling for many years, at the cost of great sacrifices and even exposing their own lives, in order to gain access to the land. The type of loyalty which they showed towards the ejido, which they recognized as the natural body to represent them, was strongly influenced by past history, in which the establishment of the ejido was only achieved after countless battles, and the operation of the ejido itself was strongly marked by the peasant movement.

Obviously, the institutional barriers do not stem from the difficulty of giving up the ejido, but rather from the difficulty of giving it up while retaining ownership of the parcel and, to a certain extent, retaining membership of the ejido. It is symptomatic

\footnotetext{
${ }^{15}$ Pare (1977) deals mainly with migration from one rural area to another. For their part, Astorga (1985) and Arispe Schloesser (1985) provide interesting interpretations of rural migration.
} 
that in the offensive against the collective ejidos in the $1940 \mathrm{~s}$, their dismantling led to the breakup of the collective forms of working the land, but not to the disappearance of the ejido. To sum up, access to the ejido parcel and to membership of the ejido were of crucial importance for the titular ejido members as an "insurarce policy".

This explanation brings in another element: loyalty and institutional barriers combine both to prevent people from leaving the ejido and from using their "voice", which in this case could have taken the form of fighting the ejido bosses. What happened, then, was a form of silent protest which was expressed both through migration and through failure to participate in the ejido assemblies. Incidentally, it would appear that the rural areas with the greatest social conflict at this time were those where collectivized agriculture was being dismantled.

This interpretation leads us to give a provisional answer to the second question as well. For the political elite of the time, who were promoting industrialization, it was obvious that the agricultural support for this process had to come from private agriculture. This is shown by the fact that virtually all State policies were designed to encourage this. But the construction of the institutional framework for sustaining this change in agricultural policies in favour of the private sector was quite a long-term process, because in the short term the governmental agencies were deeply involved in either actively supporting the ejido system or at least paying lip service to it, and furthermore there was resistance and even conflict within them regarding this change of direction. ${ }^{16}$

Moreover, commercial agriculture did not automatically respond to the promptings of the State, above all following the trauma of the expropriations under Cardenas, and the weight of ejido production, particularly in basic staples, was still considerable. Lastly, everyone could clearly see that the State had been buying social peace for many years in the countryside thanks to agrarian reform. In addition to this was the fact that the emergence of the caciques, the internal breakup of the ejidos and the marginal position to which the ejido had been relegated in terms of

16 A typical example of this was the conflict over the basic thrust of agricultural tesearch in Mexico between the Special Studies Office of the Mexican Department of Agriculture, which operaled under the auspices of the Rockefeller Foundation, and the Agricultural Research Institute which also came under the Department of Agriculture bat was influenced by the members of the League of Socialist Agronomists. public policies had not caused serious social upheavals, so that no further steps were taken towards dismantling the ejido system. In a sense, the preservation of the status quo was a result of the success achieved in the agricultural sector as a whole. ${ }^{17}$

To sum up this important point: the ejido was not privatized because on the peasants' side it was a crucial "insurance policy" that facilitated multipurpose activities and on the government side it was a vital political apparatus for maintaining stability in the countryside while allowing private commercial agriculture to be the main provider of food.

\section{Soclat mobllization for gaining access to land}

In the late $1960 \mathrm{~s}$, a number of events were to occur which changed this context and to a large extent defined the trends of the new wave of peasant mobilizations.

As commercial agriculture concentrated on lucrative crops, both for export and as inputs for the agri-food complex, giving up the production of cereals, it became urgently necessary to redirect the ejido system towards the production of staple foodstuffs and emphasize its role as a production unit, which, as already noted, had been neglected since the $1940 \mathrm{~s}$. This change in the cropping pattern was of course due to changes in the international division of labour and the presence of transnational food corporations at the end of the $1950 \mathrm{~s}$, but it was also furthered by the general policies of the government, which needed foreign currency to finance the import substitution process.

There were also other phenomena inherent in the type of rural development that these changes were bringing about. The source of these changes must be traced back to the time when State incentives for staple foodstuff production were basically concentrated on private commercial agriculture, and its high profits, based on increasing the physical volume of production through increased yields and extension of cultivated land, wene blocked by two factors: the capital needed to sustain increased yields (particularly of staple crops) or to continue with large-scale

\footnotetext{
17 From the early 1940 s up to the mid-1960s, agricultural and livestock production turned in a very dynamic performance. In fact, from 1946/48 up to 1964/66, total agricultural output grew by an average of $7.1 \%$ per year. Since at the same time the annual population growth rate was $3.2 \%$, this gave a $3.8 \%$ annual per capita increase. See Gordillo, 1990.
} 
irrigation developments, and the resurgence of peasant movements exerting direct pressure against the unlawful hoarding of land, which was the favourite way of extending the cultivated land under the control of private agriculture.

As from 1965 there were increasing signs of a major crisis in the agricultural sector, the most evident symptoms being the reduction in the land under cultivation and a decline in the growth rate of maize production in the rain-fed zones. The combination of these two indicators strongly suggests that this agricultural crisis was mainly within the ejido system. ${ }^{18}$ This crisis was the result of the unbridled decapitalization process to which ejido agriculture was subjected, and the difficulties being faced by the internal migrants in search of jobs as a consequence both of the transition towards a new stage in the import substitution process on which agricultural development depended, and the increasing mechanization of commercial agriculture. The ejido was in fact experiencing a dual crisis: a production crisis and a social reproduction crisis.

Commercial agriculture gradually gave up the production of cereals and tended to replace them with fodder crops and the soya-sorghum complex, along with the development of livestock raising, which took away extensive areas that had previously been devoted to cereals production. Because of the decapitalization process to which it was subjected, the ejido system could not fill this vacuum, and since between $35 \%$ and $45 \%$ of all ejido households in those years were unable to derive even half of their income from on-farm activities, and were facing increasing difficulties in finding off-farm incomes, the impossibility for the ejido as such to build up an accumulation fund of its own was coupled with the increasing difficulties facing households in covering their own consumption needs. The ejido system's response to all this was a reduction in production output, due both to the greater emphasis on self-consumption and to the reduction of the land under cultivation, which, as already noted, led to the agricultural crisis at the end of the 1960s.

These same circumstances gave rise to another and apparently paradoxical phenomenon: because of the greater pressure on ejido agriculture, despite the difficulties in the off-ejido labour markets this situ-

${ }^{18}$ See the statistics given in the article by Gomez Olivier, 1978 , pp. 714-727. ation gave rise to permanent migration flows, which were largely responsible for the explosive growth in the poverty belts around the large towns, the emergence of peasant towns adjacent to the commercial agriculture zones, and the appearance of peasant ghettos in the large towns and cities (i.e., neighbourhoods or settlements inhabited by people from the same peasant region, who not only maintained their cultural and affective bonds with their communities but also estabished a permanent flow of economic assistance). As in the previous period, however, these migration flows that were now permanent presupposed that the legal bond with the ejido was maintained, and not broken.

Another phenomenon was also beginning to emerge very noticeably: the generational takeover from the original ejido members, because it should be borne in mind that most of the original ejido members teceived their lands between 1930 and 1940 . Even though the land distribution did not stop, and between 1964 and 1970 it was actually stepped up, ${ }^{19}$ the number of ejido members involved and the geopolitical location of the first ejidos made this generational takeover quite significant.

The form that it now took was quite different from that observed in the case of the first generations of ejidatarios, but perhaps what was most important was the combination of: i) a process of fragmentation of the ejido parcel, giving access to land to the eldest son, albeit in a very unstable manner; ii) the formation of committees of applicants for land, made up basically of other sons of ejidatarios and neighbours, which asked the authorities to expand the original ejidos; and iii) permanent or temporary emigration of some of the other siblings, following a pattern in which part of the household went out to a particular

19 According to official figures, under the presidency of Diaz Ordaz, 24 million hectares were distributed, 16 million more than in the period of Cárdenas. The quality of the land distributed becomes very clear when one compares the number of ejido members benefitted in the two periods: under the presidency of Díaz Ordaz, about 300,000 household heads received land, compared with just over 750,000 under Cárdenas. In the period from 1964 to 1970 the land distribution figures also included land distributed in other periods but actually delivered turing that period. A legal reform was also introduced which defined the land delivery procedure as being the allocation of land a great distance away from where the applicants originally lived ("nuevos centros de poblacion"). The real intention was to relieve the pressure on the large estates of irrigated land, but in many cases the result was that the peasants declined to move to other regions. Nevertheless, the land was recorded as having been distributed. 
migration area in advance of the others, settled down there and subsequently formed a base so that the other members of the household could join them later as temporary migrants.

The 1960s were characterized by great instability in peasant households, not only as a result of migration but also because of a great many conflicts within households, between households, against the ejido caciques, etc., all basically due to the desire to gain access to an ejido parcel.

Within the ejido, more and more people were clamouring for a change in the system. This represented a direct challenge to the bosses and a slow and sometimes underground process carried out through the formation of committees of applicants for land made up of the sons of ejido members and settlers on the ejidos. In one way or another the creation of these land-demand committees also created new ways of thinking, directly related to the operation of the ejidos, and activated the historical memory of the originat members. Furthermore, the inhabitants of the ejidos found that they were becoming enormously more influential in terms of the government's response to their mobilisation -even though it was normally limited to their particular ejido- and their boycotts, which in this case took the form of refusal to work their land (Hirschman, 1977, pp. 86-87).

All these processes led to a new wave of peasant protests, starting in the $1970 \mathrm{~s}$ and still continuing to this day.

\section{III}

\section{The dynamlcs of polltical control (1970-1988)}

The govermmental response to this crisis was typical of political cycles in Mexico. For thirty years after the Cardenas regime the policies he had implemented in the countryside were either flatly rejected as populist or simply considered outdated policies of a historic period which had now passed. But in 1970 the newly elected regime headed by Luis Echeverria badly needed new legitimation following the bloody repression of the student movement in 1968, and in addition it was confronted in the countryside with a new wave of peasant mobilization more widespread than any seen since the 1930s. Faced with new demands for land coming from the ejido members, and with incipient but clear signs of stagnation in agriculture and livestock production, the regime resorted to the arsenal of Cardenist policies and measures, with the clear intention of revamping the socjal pact that had been of crucial importance in the $1940 \mathrm{~s}$.

In order to do this, the Echeverría regime introduced two major changes. Firstly, like the Cardenist school of thought, it again considered the ejido as the main hub of State intervention and as the basic production unit for guaranteeing food production and self-sufficiency. The Agrarian Law, which had not undergone any major changes since 1946, was completely reformed, with the introduction of a new chapter regarding the "economic activities of the ejido". At the same time, a new set of institutions were either created or given broader mandates to implement the legal changes. No regime before, including the Cárdenas regime, had engaged in such a broad range of interventions as those resulting from Echeverrfa's reforms. A new ministry (the Ministry of Agrarian Reform) was set up in the 1970s, and the ministries of agriculture and of water resources were merged into a single powerful body. New para-State bodies were also created through various mergers to provide such services as rural credit, foodstuff distribution, agro-industrial development, production and distribution of inputs, etc., thus greatly expanding the scope of State intervention.

Secondly, the govemment sought to deal with the peasant mobilization -mainly conducted by grassroots groupings that were questioning the dominant role of the official peasants' organizations- by trying to revitalize the corporative arrangements. Although during the first year of the new regime cases of illegal occupation of land were severely punished, using army troops for the purpose, very soon the wide extension of the mobilizations forced the government to try controlling them by agreeing to use its discretionary powers to confiscate private land and distribute it to landless peasants. Indeed, by the end of the Echeverria regime major expropriations of land had been carried out in the irrigated districts where the best-quality land was to be found, and the 
distribution of land rose to one of the highest levels since the time of Cárdenas. This gave rise to a profound political crisis, with both peasant organizations and private farmers dissatisfied with the government's performance.

But what was perhaps the most important feature of this period was the extent to which the system of political control was refined and extended to the reformed sector. After having analysed the ejido from a bistorical perspective -limited of course to the twentieth century- we will now review the interaction amongst its different components, taking its role as an instrument of political control as the basic driving force. It is important to keep in mind that the State's shaping of the ejido into an instrument of political control happened slowly and unevenly across the country. Ejidos have always been highly diverse and heterogeneous. They differ not only in their natural resource endowments but also in their membership composition and the different trajectories of their struggles for land. While acknowledging this diversity, however, it is still possible to analyse the model of political control that was applied to all ejidos. This model operated at three levels: the legal framework, political representation, and social reproduction. All these levels operated simultaneously but with varying intensities depending on the period and the region. While the government's organizations and the format of State intervention have thus differed, they have all been based on a model of control that was authoritarian, hierarchical, yet inclusive.

\section{State Intervention in ejido affairs}

There were specific legal codes that very strictly regulated the organization of production within the ejido and laid down the rights and obligations of the ejidatarios. For example, the ejidatarios had to work the land directly; they could not hire wage labour. They could not rent the land or sell it. Absences from the ejido of more than two years led to loss of right to the land. All ejidatarios had to establish the order of heirs to their land in writing, usually naming a spouse or partner as the preferred successor. Ejidatarios could vote for and be elected to the Executive Committee of the ejido's Assembly. They could also vote on the definition of an internal set of rules that regulated their rights, particularly their access to the community's common lands. Each ejidatario also had the right to an urban lot on which to establish a residence and to a maximum of twenty hectares of land for direct cultivation.

Access to land could be gained in any of four ways. For an indigenous community with legal documentation, access to the land was gained through the right of restitution. If a person lived in a human settlement where land was available for distribution within a certain radius, he or she could obtain land through a grant. If an individual was willing to relocate to another region or state, he or she could obtain land in colonization zones where new population centres were being promoted. Finally, existing ejidos could obtain an extension of their land and thus incorporate new ejidatarios. ${ }^{20}$ In the last decade before the recent reforms, the government allowed the incorporation of households whose members had the title of ejicatarios but had no land (ejidatarios con derechos a salvo).

A number of mechanisms existed through which the State intervened in the internal life of the ejidos to impose the law (Whetten, 1948; Fernandez y Fernández, 1973):

i) There was State intervention aimed at legalizing the ejidos' internal decision-making processes. For example, almost all important decisions were made in the ejido assembly: distribution of urban lots and plots for cultivation; approval of internal rules; requests for credit and other public services such as schools, running water systems, or roads; regulation of access to collectively used lands; and definition of forms of work within the ejido. However, to make an assembly's decisions valid, a representative of the Ministry of Agrarian Reform (SRA), formerly called the Agrarian Department, had to be present. Furthermore, calling an ejido assembly was only considered legal if a representative of the SRA or of the municipal authority endorsed it. Extraordinary assemblies could only be convened by the SRA.

ii) The State intervened in ejido arbitration matters. For example, family controversies about the use of land plots or conflicts regarding inheritances had to be settled in State administrative tribunals. These tribunals were part of the structure of the Ministry of Agrarian Reform and they also settled boundary disputes between ejidos, between ejidos and private landowners, and between ejidos and indigenous communities.

\footnotetext{
${ }^{20}$ The legal names for these four processes are restitución, dotación, nuevos centros de población, and ampliación.
} 
iii) The State controlled the flow of public resources to the ejido. Since the late $1970 \mathrm{~s}$, commercial banks have made loans to ejido members, but before that time only official State banks offered this service. In order for an ejidatario to receive credit, an official authorization from the ejido assembly was required. However, the credit was given to the ejido. Thus, all its members were co-liable for the total amount of credit received and had to offer their harvest as collateral. In order to secure this collateral, the official bank established agreements with the ejido, with each member who had received credit, and with the State organization that marketed the ejido's crops and livestock production. This marketing organization, CONASUPO (the National Basic Foods Company), bought the harvest at an established guaranteed price and issued cheques to the ejidatarios and the official bank. Part of the credit was paid in kind. If the credit was for fertilizers, FERTIMEX, the para-State organization for the production and distribution of fertilizers, was responsible for repayment. If the credit was for insecticides, other chemical products, or machinery, the bank established contractual arrangements with the respective private enterprises. In the irrigation districts, an irrigation permit was also required. This permit was issued by the Ministry of Agriculture and Water Resources (SARH), previously called the Ministry of Water Resources and, before that, the National Irrigation Commission (Gordillo, 1988b).

Until very recently, all borrowers from the official bank were required to purchase crop insurance from an official institution. There were also State enterprises that operated all along the commercial chain in coffee, cocoa, sugar cane, tropical fruits, and other specialized crops. These para-State bodies provided credit, purchased the harvest, and supplied technical assistance and inputs as well. In every case, an ejido assembly was required to agree on the ejido's participation in the programme. Overwhelmed by so many State requirements, the ejido assemblies could at best only discuss policies initiated by the government, stifling initiatives that could have emerged from the ejidatarios themselves.

iv) The State also intervened in a wide range of social welfare and infrastructure services. The Ministry of Education established schools and provided teachers. Public organizations for health, housing, food aid, roads, ethnic issues and recreational activities also intervened. This extensive State intervention in social services was focused in particular on the indigenous communities and poorest ejidos, which contributed to the development of a functional distribution of government agencies across ejidos and a deepening of heterogeneity in the rural sector: while the social development agencies concentrated on meeting the needs of poor ejidos and indigenous communities, the agencies promoting production attended to the demands of private producers and the more prosperous ejidos.

\section{Political representetion}

At another level, the political control model operated through different forms of political representation in the ejido, with pervasive political interventions. Until the mid-1980s, with a few exceptions during the $1950 \mathrm{~s}$ and $1960 \mathrm{~s},{ }^{21}$ in order to gain access to public goods and services, ejidatarios must belong to the National Peasants' Confederation (CNC), which in turn was affiliated with the ruling Institutional Revolutionary Party (PRI). Thus, through decisions of the ejido assembly or more frequently of the ejido's executive committee, the ejidatarios were made members of both the CNC and the PRI. It is worth emphasizing, however, that although the model of political control was authoritarian, it was also inclusive. In other words, it did not aim at excluding the rural social actors but rather at incorporating them into rural governance. The State accomplished this through different levels of peasant organizations.

The first level comprised the corporative organizations, which were given preferential treatment by the State. At first these organizations were eminently political, because of the links connecting the ejido executive committees with the regional committees, the state leagues, and the CNC. During the 1970s, however, as a consequence of the first substantive modification of the agrarian law in almost thirty

\footnotetext{
${ }^{21}$ During those years, two major splits occurred in the uncontested political monopoly of the CNC. These splits gave bitth to four organizations: the Unión General de Obreros y Campesinos de México (UGOCM), the Central Campesina Independiente (CCI), the Consejo Agrario Mexicano (CAM), and the Central Independiente de Obreros Agricolas y Campesinos (ClOAC). The first three organizations were subsequently incorporated in the official political party (PRI), but CIOAC has always been loosely linked to leftist parties.
} 
years, ${ }^{22}$ the economic organization of the ejido came to be the favoured form of corporative organization. That is why, in the 1970s, the first ejido unions and Rural Collective Interest Associations (ARICS) were formed. Since all forms of economic organization had to stem from government initiatives and were used to facilitate the implementation of government programmes, major efforts were made to include the rural population through this mechanism. New forms of organizations were established to incorporate new social groups. For example, the UAIMs (AgroIndustrial Units for Women) were also created in that decade. During the 1980s, youth organizations, Community Committees for the Distribution of Foodstuffs (Consejos Comunitarios de Abasto), and specialized organizations for specific products were created (among other organizations) within the ejidos. Whenever there was an important new national objective, a new widespread demand in the countryside, or a favourite programme of the current President, new organizations were established. Even though this was not the original purpose, the creation of these organizations increased the negotiating capacity of the ejido, giving rise to a new generation of peasant leaders.

The second level of peasant organization was based on traditional community organizations, which had been present since time immemorial. They were grounded on reciprocity, with organizations for mutual insurance, collective labour, and labour exchange. In most ejidos, these organizations adapted to changing circumstances but they never disappeared. Since the official criterion to determine whether peasants were organized or not was the number of formal organizations that existed, these community organizations were not considered and it was always assumed that peasants were not organized.

The third level of peasant organization consisted of entities that had previously existed only on paper -because they had been artificially created by the government- but were transformed into representative organizations. The process whereby existing formal and informal community institutions -ejido unions, Rural Collective Interest Associations, cooperatives, etc.- were converted into representative organizations was a result of mobilizations on behalf of ad hoc causes.

${ }^{22} \mathrm{~A}$ new agrarian law was promulgated during the presidency of Luis Echeverria (1970-1976).
The coexistence of these different levels of peasant organization was largely the result of a nonintentional separation of functions. Corporative organizations established the links between the State and peasants, while community organizations estab. lished relationships of solidarity among members of the community, and representative organizations emerged when traditional channels for posing demands failed to work.

\section{Secondary markets as a source of social reproduction}

No model of political control is perfect, especially in the absence of a pre-established plan. Because the model evolved as it was being implemented, many aspects emerged randomly. Several' elements of the model contradicted each other, and the instruments of control varied from one Presidency to the next. There were, however, two features of the model that did not vary. Its inclusive nature was maintained, which means that, rather than excluding new social agents or possible dissidents, the State usually tried to coopt each group under the existing roles, and there was a strong agrarian ideology, which helped to hold the structure of the ejido together. This ideology was organized around two basic themes: i) the alliance between the peasants and the State, with the supposed objective of assuring the progress of the former, and ii) the need to resort to State agents as intermediaries between peasants and the rest of national society.

However, it seems to be a feature of all societies that every State intervention in political or economic markets -particularly interventions sustained over a long period of time- creates countervailing responses and secondary markets. The model of State control over the ejidos was no exception. For example, the prohibition against selling ejido land created a secondary market (Warman, 1980; Gledhill, 1991). Widows and ejidatarios who had migrated for good were the primary participants in land sales, while sales of surplus lands or part of an ejidatario's land to resolve severe economic crises were the primary sources. The prohibition against renting land created an even more active illegal market, especially in irrigated areas. From the ejidatarios' point of view, the temporary rental of a plot of land was a means of economic recovery in case of hardship. Frequently the illegal rental of ejido land was related to migration (De 
Walt, 1979). In some cases, the rightful ejidatario migrated for an extended period of time and rented the land to circumvent the rule that prohibited him/her from leaving the ejido for more than two years. In other cases, an old ejidatario or his widow rented the land because they had no children to help work it. Alternatively, wage labour was hired to replace the labour of family members who had migrated. The ejido assembly, which had to be held monthly in the presence of a government official, was frequently conducted without the official's presence, although the latter nevertheless established his presence ex post facto in order to obtain favours and perquisites. Sometimes assemblies that had never taken place were invented, with the connivance of the government representative. Credit, insurance, roads, and schools could be obtained in this way, and this method also served to expel ejido members, incorporate new ejidatarios, and dismiss ejido Executive Committee members.

The secondary markets generated their own political and economic agents: the ejido bosses. Since all black markets break the law, it was necessary for these agents to legalize their offences. For example, selling a plot of land was legalized through a process of elimination of ejidatarios and new assignments (depuración y nuevas adjudicaciones). The seller of the plot ceased to be an ejidatario at the time of sale, adducing any legal reason that would suffice, while the buyer was incorporated as a new ejidatario. Also, a member of the ejido who left for more than two years could be excused from working the land for "health reasons". Without such mechanisms, many of the peasant leaders who had stayed away from the ejido for twenty years or more would have lost their land. Sometimes an ejidatario would not leave officially but would "lend [his land] without compensation" to the ejido executive committee or to a person authorized by the committee, although in fact he did so in exchange for money. The same system was used for renting land. To cover up an ejidatario's absence, his name would always appear on the list of those present at the ejido assemblies. Furthermore, the ejidatario was on the credit list of the official bank and even on the list of those taking out insurance with the State firm. To compensate tenants for the shortness of the rental period (which was necessary because of the illegality of the transaction), the ejidatarios who rented their land also allowed their respective tenants to use their names. In this way the tenants gained access to official credit, which was subsidized. Some private landowners in northeastern Mexico went so far as to rent not only ejido parcels but even entire ejidos.

Some of the secondary markets that emerged from State interventions in economic matters became highly lucrative businesses. For example, the "disaster business" consisted of feigning damage to the harvest and collecting the crop insurance. In order for this to work, the cooperation of an ejido executive committee member was necessary, because he or she was the first to be notified of the "disaster". The cooperation of representatives of the Ministries of Agrarian Reform and of Agriculture and Water Resources was also necessary, because they were responsible for verifying the supposed disaster Insurance company agents, official bank representatives, and of course the ejidatario himself all cooperated in confirming the "disaster" too. The ejidatario collected the insurance for the "damaged" harvest and then sold the same harvest through regular market channels. For the ejidatario, this was a way of counterbalancing the low guaranteed prices or simply making a little extra money. And what did the other participants in the deal gain? This is where the official bank agent came in. Credit had been given to the ejidatario in installments. The last installment paid out before the disaster claim was filed was endorsed over to the official bank agent, who then collected the money and distributed it to the whole chain of collaborators in this peculiar business (Rello, 1987).

In short, the reproduction of the ejido was supported by secondary or "black" markets. These played an important role in adapting State political and legal interventions to the logic of peasant society and economy. This interaction between two different and frequently contradictory logics affected the way both of them functioned, making them compatible, if not convergent. But of course the efficiency and equity costs were enormous, both in resource wastage, in public budget deficits, and in the welfare levels of the ejidatarios. 


\section{IV}

\section{Reforming agrarlan reform (1982-1994)}

\section{The convergence of opposites}

The reforms in the countryside that were implemented during President Salinas's regime (19881994) addressed two basic areas: the relationship between rural producers and the State, and the relationship among productive agents in the countryside (Gordillo, 1992).

During the last twenty years, peasants successfully developed mechanisms of resistance to the implementation of public policies in rural areas. The State, with its instruments of intervention and control, was increasingly seen as an enemy by the different social agents in rural areas. Frequently, economic problems became politicized and stirred up confrontations that had paradoxical effects. The very same State policies that suffocated the ejidos also increased the latter's demands for more State support.

As a result of the debt crisis of 1982 and the subsequent implementation of stabilization and adjustment policies, a rural development strategy based on the pervasive presence of the State ceased to be economically viable. The State had intervened through very diverse means, including selective indirect subsidies, which were usually regressive. This strategy was very costly for the State because it depended on the massive disbursement of subsidies, and the model soon became highly inefficient. Subsidies were channelled not only to the ejido sector but also, and indeed mainly, to the private sector in agriculture. These subsidies had different purposes: for the ejido sector, they were intended to grease the machinery of political control; for the private sector, they sought to stimulate production. It was the private sector that was assigned the classical role of agriculture in an import substitution model, providing foreign exchange and cheap food. The model of political control became inefficient because it had been developed for a closed society organized into corporative segments. The winds of political mobilization, which started to blow strongly in Mexico after the student movement of 1968 , began to erode this authoritarian model, and the State's legitimacy came to depend increasingly on electoral processes and greater political openness. At the same time, the 1982 debt crisis also helped to shatter the economic model that had prevailed in Mexico since the 1950s.

Consequently, political control and economic subsidies decreased, creating an exceptional opportunity for convergence between free-market macroeconomic policies and social mobilization. Economic policy -which focussed mainly on trade liberalization, deregulation and privatization- converged with social mobilization objectives, which focussed on restncturing peasant representation through political liberalization, in rejecting State intervention. This convergence was neither premeditated nor deliberately promoted by government or civil society. On the contrary, economic liberalization was to be accomplished by modifying and using political authoritarianism, not abolishing it. Similarly, the strategy of political liberalization -and in some cases democratization- was meant to preserve the economic privileges gained through State subsidies.

How did these two opposing tendencies come to converge? There was never an articulated policy combining both strategies. Rather, what happened was that the juxtaposition of policies had created an institutional vacuum. The political control model depended on State intervention. However, the State enterprises responsible for this intervention were largely privatized, and their control loosened when they found themselves in financial crisis. The political clientele supported by these enterprises prevented their complete privatization, and many State enterprise assets were instead transferred to rural producers. For example, the basic instruments of political control in the countryside were affected when BANRURAL (National Rural Credit Bank) ran into financial difficulties and land distribution ceased. However, peasant resistance prevented the complete disappearance of the official bank and led to the emergence of alternative mechanisms such as the credit without collateral provided by the National Solidarity Programme (PRONASOL), and, more recently, the establishment of credit unions. Peasant resistance also 
prevented the total cancellation of land distribution and obtained a promise to negotiate about lands still in the process of allocation. This very particular convergence hejped to remove obstacles, but it did not lead to the creation of new institutions.

The economic reforms sought to abandon the system of guaranteed prices and align internal prices with international ones. But the juxtaposition of the two currents, economic and political liberalization, caused two crucial problems. First, the system of guaranteed prices, which had covered twelve products, disappeared, but guaranteed prices were maintained for maize and beans. No reasonable adjustment scheme was ever prepared for smoothing the process of price alignment and trade openness, which dramatically changed the marketing of agricultural products and increased peasant indebtedness. At the same time, maintaining guaranteed prices for maize and beans generated extraordinary rents for some producers. The agricultural sector turned en masse to maize production, and agriculture evolved toward monoculture instead of diversification.

The reform of Article 27 of the Mexican Constitution in 1991-1992 helped to further dismantle the political control model. The promoters of economic liberalism saw this reform as a way to free the ejido's production potential and create a market for land. To implement their plans (especially the more unpopular measures) they counted on the effectiveness of the political control model. The promoters of political liberalism, on the other hand, saw the reform as dismantling the political control model but not the system of economic rewards that it provided. Both perspectives were utopian. One looked toward decreasing economic intervention while maintaining political control. The other looked toward decreasing political control while maintaining economic intervention. The contradiction between these two positions created serious institutional gaps that allowed the emergence of an incipient peasant production system but also seriously jeopardized the effectiveness of the reforms put in place.

\section{A truncated peasant economy}

After examining the complexities and contradictions of political control over the ejido, one wonders how it managed to survive for so long. As already noted earlier, the answer lies in the dual role of the ejido as an insurance device and as a political apparatus. We will now deal with its role as an insurance device, which is another way of saying that the ejido played an important role as a body of peasant representation. This is clearly linked with the particular form of operation of the peasant economy. It is well known that the peasant economy is based on the household as a production and consumption unit and on a series of mutual assistance practices between the households in a community. The ejido provided this peasant economy with an institutional arrangenent that linked these two crucial elements with a third element of equal importance: access to common property resources.

However, the way the political control model was implemented distorted the three elements of the ejido peasant economy. The adjudication of land plots to the head of the household, and the almost complete absence of legal rights for the other household members, sowed seeds of conflict. It is apparent, when reviewing ejido conflicts over the past decades, that family disputes were common -conflicts between fathers and sons, between husbands and wives, and among children. These conflicts have escalated because enormous demographic transformations have taken place in the ejidos, particularly since the 1970 s, but the ejidos have not had the necessary flexibility to accommodate these changes. The original ejidatarios have aged, and many new settlers (avecindados) have come to the ejido villages (sometimes outnumbering the ejidatarios), even though they could not acquire the status of official members of the ejido. Another inportant factor has been the extensive migration to other parts of the country and to the United States.

Traditional peasant production practices based on native seeds, biological control, organic fertilizers, animal traction and intercropping were degraded by a truncated process of technological modernization that was initiated by government organizations for research and development in agriculture. Indeed, until recently intercropping was expressly excluded from credit support despite its being a cornerstone of peasant farming systems. There were also no clear rules about access to common lands. This has led not only to illegal appropriations of land but also to the acceleration of social differentiation within the ejido and to severe ecological degradation of ejido resources. Thus, the ejido sector had become a truncated peasant economy that coexisted with a 
State model of political control: in other words, it was a repressed peasant economy in the grip of the State. The ejido was both the apparatus that embodied the State's political control over peasants and the form of organization of production and representation that allowed the peasant logic to be utilized and reproduced. Compatibility between State logic and peasant logic had been achieved through the existence of secondary markets that combined controls and subsidies, but inevitably, when this unstable equilibrium started to fall apart, the political control model was also decisively affected.

When using the term "peasant production system", it is necessary to guard against any Chayanovian interpretation of this peasant agriculture, as well as against any revival of the old peasant extinction/survival polemic that raged in the 1970s in Mexican academic circles. The peasant production system referred to here is characterized by its search for a form of integration in the market system: a position based on the comparative advantages of ejido agriculture vis-à-vis private agriculture. Ejido agriculture has an advantage because of its reliance on family labour, community organization, access to collective resources, strong participation in labour markets, and particularly its reliance on national and international migration.

We will now turn to the basic traits of this peasant production system and the way they developed in the context of the changes that occurred in the ejido sector between 1990 and 1994. Comparison of the results of the 1994 ejido survey conducted by the Ministry of Agrarian Reform and the University of California at Berkeley with those of the survey carried out in 1990 by the Ministry of Agriculture and Water Resources and ECLAC will help to give an idea of the transformation of the ejido sector in the midst of a profound crisis in the entire Mexican agricultural sector (de Janvry, Gordillo and Sadoulet, 1997).This larger crisis has been marked by adverse economic incentives, shrinking public support and wide institutional gaps.

In the following analysis of farm sizes, individual plots of land are measured in hectares of national rainfed equivalent land (HNRE), which correspond to the observed average yields of rainfed maize, by agroecological region, in order to adjust area for quality differentials. The unit of measurement is a hectare of rainfed maize that produces the 1994 national average yield of 1.09 tons. a) Concentration of the land in small holdings ${ }^{23}$

If the ejidatarios are classified by the size of their plots and their geographical region, we observe that between 1990 and 1994 there has been a process of concentration of small holdings in most regions except in the Pacific South. There has thus been a slow process of elimination of the most extreme forms of minifundio. This suggests that a partial solution to rural poverty could be found through the abandonment of the smallest plots, i.e., through migration and non-farm employment. Several aspects of the ejido reforms have contributed to this abandonment. One is the newly acquired freedom to rent land, which has allowed the smallest farmers to rent out their land and engage in other activities. The other is greater flexibility to participate in off-farm activities and migration without the threat of losing land rights in the ejido. The decline of the minifundio has been less rapid in the Gulf and Pacific South regions, where indigenous attachment to the land is more prevalent and from where migration to the United States is not as intense. In these two regions, where the incidence of extreme poverty is highest, a solution to rucal poverty thus cannot be expected to come simply from migration and export of the poverty problem to other sectors and regions.

\section{b) Consolidation of peasant farming systems: inter-} cropped maize cultivation

One of the most notable features of the 19901994 period has been the expansion of the land planted with maize. This has been induced both by price distortions that favour maize over other crops and by price guarantees that eliminate the element of risk. Maize has thus been a relatively attractive crop during the last four years. In the ejidos, the result has been a $20 \%$ increase in the area planted with maize in rainfed areas and a $68 \%$ increase in irrigated areas. On rainfed land, $66 \%$ of the increase corresponded to monocropping and $34 \%$ to intercropping. The first is typical of farms with a greater commercial orientation and the latter of peasant farming systems. Most of the increase ( $84 \%$ ) came from farms of more than 5 hectares of NRE, where land formerly in pastures and fallow was shifted to maize. Most of the increase in intercropped maize $(72 \%)$ occurred on smaller

${ }^{23}$ This section is based on de Janvry, Gordillo and Sadowlet (1997). 
farms, where it reflects the use of typical peasant farming systems. On irrigated land, $91 \%$ of the expansion in maize cultivation was on the larger farms, where it displaced traditional cereals such as wheat and oilseeds, and $97 \%$ of this expansion was in monocropped maize. On the smaller farms, there was an increase in intercropped maize. On the larger farms, the expansion was principally in commercial types of monocropping, which accounted for most of the aggregate expansion. The response to incentives to produce more maize thus accelerated the process of differentiation, with smaller farms increasingly specializing in peasant farming systems and larger farms in commercial farming systems.

\section{c) Technological regression}

It is clear that there was a severe retrogression in the technological level of the ejidos on virtually all fronts and across all types of farms during the 19901994 period. Looking again at maize, the only exception to this technological regression was the diffusion of improved seeds on the larger farms. For the rest, there was a sharp decline in the use of chemical products and fertilizers. The sector was virtually abandoned in terms of access to public technical assistance, across all farm sizes. Simultaneously, there was a general increase in the use of manual labour in agricultural work and a decline in the use of machinery. The sector thus coped with the profitabil- ity crisis by using less technology per unit of production and reverting to family labour.

\section{d) Strong orientation towards production for home} use

In order to bring out the prevalence of a peasant economy and the depth of social differentiation within the ejido sector, we may look at the degree of participation of ejidatario maize producers in the market for that cereal, either as sellers or as buyers. We thus see that $41 \%$ are sellers or seller/buyers of maize, while $27 \%$ are pure buyers. Another $31 \%$ are self-sufficient, using the maize they produce principally for home consumption $(24 \%)$ and to a lesser extent for feeding animals $(7 \%)$. This reveals a sharply differentiated universe of maize producers, where less than half participate in the market as sellers. It is this group of sellers that will be hurt if there is a fall in the price of maize, as is expected under NAFTA. The other $59 \%$ will either not be directly affected by maize prices or will actually be benefited by falling prices as net buyers. These net buyers and self-sufficient producers without large herds of animals are smallex farmers with little irrigated land. The existence of a strong peasant economy will thus cushion the negative effect of a fall in the price of maize, which will have a sharply differential effect across different categories of maize-producing households, depending on their position with regard to the market for this cereal.

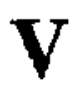

\section{Some conclusions for the near future}

The changes observed in the ejido sector between 1990 and 1994 therefore reflect the following phenomena:

- The impact of macroeconomic policies, characterized by effective control of inflation but also by a serious profitability crisis in agriculture linked to decreasing global growth rates, increasing appreciation of the real exchange rate, a fall in the real support prices of the main staple crops, high interest rates, and the loss of subsidies to the sector.

- An institutional vacuum created by the decline in the State's role in agriculture, leading to the privatization, scaling down or liquidation of many of the public institutions supporting the sector and only a very partial reconstruction of alternative institutions to support the ejidos. In general, this reduced the availability and raised the cost of access to credit, insurance, markets, modern inputs, seeds, water, and technical assistance.

- The beginning of a process of adjustment to the new economic and institutional rules by ejidatarios and by the ejido as a form of organization.

By 1994 , the changes in the legal statutes codifying the use and ownership of ejido land had already activated the land rental market. The reforms had also liberalized individual and community initiatives, allowing numerous adjustments in the production sys- 
tem, in household income -earning strategies, and in the organization of the ejido- adjustments that had been prohibited before the constitutional reforms or had been carried out illegally.

What we observed between 1990 and 1994 was thus an ejido sector in crisis, at the initial stages of a long process of adaptation and transformation. The obvious difficulties that ejidatarios confronted were partly contextual and structural, but they were also symptoms of a difficult and protracted process of transition towards economic and political liberalization.

We may conclude by observing that the outcome of the second Mexican agrarian reform process initiated by President Salinas is still far from certain. Liberalization of the ejido has unleashed numerous individual and collective initiatives that have produced visible adjustments, showing the ability of this vast sector to respond to incentives. At the same time, the overall context of economic crisis in agriculture and dismantling of rural sector institutions has reduced the economic benefits that the reforms could have yielded, and hence the scope of the modernization and diversification that was expected to follow. The main step in the reforms -namely, the individual titling of ejido lands in usufnuct- has hardly begun. And the ultimate outcome of the reforms is tied to the resolution of much broader economic and political questions with which Mexico is still struggling: on the economic side, restoration of economic growth, maintenance of a competitive real exchange rate, and creation of jobs; on the political side, implementation of participatory democracy, decentralization of government, and enforcement of the rule of law.

What is certain is that this second agrarian reform process offers major opportunities to improve efficiency and welfare in the ejido sector. Years of neglect and cumulative contradictions between the functions of the ejido as a mechanism for simultaneously achieving political control over the peasantry, representing peasants, and organizing production by smallholders had created a huge efficiency gap that now needs to be filled. Analysis of success stories can help to identify the measures that must be pursued to fill this gap (de Janvry, Gordillo and Sadouiet, 1997). They include a favourable macroeconomic environment, institutional reconstruction, promotion of organizations (in particular through the ejido system), and public investment in irrigation and education. The agrarian reform initiative needs to be complemented by a comprehensive programme of rural development in support of the land reform beneficiaries: a programme that still needs to be put into place (de Janvry and others, 1996). Because of the high level of heterogeneity of farm households, a rural development programme for the ejido sector should focus not only on agriculture but also on the other sources of income accessible to ejidatarios. This means that it will be necessary to coordinate the interventions of a whole range of public and private institutions. Unless these measures are rapidly implemented, the majority of smallholders in the ejido sector are unlikely to be competitive, and they risk being displaced by a small number of well-endowed entrepreneurs in the ejido and the private sector as the land market is perfected. Failure to be competitive would thus lead to massive displacement of smallholders and to pressures on the urban labour markets and the border to the north. In the interests of global economic efficiency, the welfare of a large segment of the Mexican poor, and political stability, it is therefore urgent that the agrarian reform process under way should be complemented by a broader range of initiatives to help the agrarian reform beneficiaries to become competitive in the new economic and institutional context before the process of granting title deeds is completed and the market for land sales is activated by the reforms.

(Original: English) 


\section{Bibliography}

Arispe Schloesser, L. (1985): Campesinado y migración, Mexico City, Editorial Sep-Cultura.

Astorga, E. (1985): El mercado de trabajo rural en México, Mexico City, Editorial Era,

Castillo, C. M. (1956): La economía agraria de El Bají, Problemas agrícolas $e$ industriales de México, vol. III, Nos. 3-4, Mexico City, July-December.

Córdova, A. (1973); La ideología de la revolución mexicana, Mexico City, Editorial Era.

(1974): El cardenismo y la política de masas, Mexico City, Editorial Era/El Colegio de Mexico.

de Janvry, A., G. Gordillo and E. Sadonlet (1997): Mexico's Second Agrarian Reform, La Jolla, California, University of California, Center for US-Mexican Studies.

de Janvry, A. E. Sadonlet, B. Davis and G. Gordillo (1996): Ejido sector reforms: From land reform to rural development, in L. Randall (ed.), Reforming Mexico's Agrarian Reform, New York, M. E. Sharpe.

de Janvry, A. and E. Sadoulet (1989): A study in resistance to institutional change: The lost garne of Latin American land reform, World Development, vol. 17, No. 9, Oxford, U. K., Pergamon Press

De Wall (1979): Modernization in a Mexican Ejido: $A$ Study in Economic Adaptation, Cambridge, MA, Cambridge University Press.

Fernández y Femández, R. (1973): Cooperación agrtcola y organización economica del ejido, Mexico City, Secretarfa de Educación Pública.

García Treviño, R. (1956): Agrarismo revolucionario y ejidalismo burocrático, Problemas agrícolas e industriales de Mexico, vol. III, Nos. 3-4, Mexico City.

Gledhill, J. (1991); Casi nada. A study of agrarian reform in the homeland of Cardenismo, Austin, Texas, University of Texas Press.

Gómez Olivier, L. (1978): Crisis agrícola, crisis de los campesinos, Revista de comercio exterior, vol. 28,
No. 6, Mexico City, Banco Nacional de Comercio Exterior, June.

Gordillo, G. (1988a): Campesinos al asalto del cielo, Mexico City, Siglo XXI Editores.

- (1988b): Estado, mercado y movimiento campesino, Mexico City, Ed. Plaza y Valdés.

- (1990): Reformando a la revolución mexicana, Mexico City, Ed. El Nacional

- (1992): Más allá de Zapata, Mexico City, Ed. Cal y Arena

Hirschman, A. O. (1977): Salida, voz y lealtad, Mexico City, Fondo de Cultura Economica (FCE)

Krauze, E. (1971): Caudillos intelectuales de la revolución, Mexico City, Siglo XXI Editores.

Orozco, W. I. (1895): Legistación y jurisprudencia sobre terrenos baldtos, Mexico City, El Tiempo.

Paré, I. (1977): El proletariado agricota en México, Mexico City, Siglo XXI Editores.

Prseworski, A. (1985): Capitalism and social democracy, London, Cambridge University Press.

Rello, F. (1987): State and Peasantry in Mexico: A Case Study of Rural Credit in La Laguna, Geneva, United Nations Research Institute for Social Development (UNRISD).

Torres, B. and L. Medina (1978): Historia de la revolución mexicana, tomo 18, Mexico City, El Colegio de México.

(1979a): Historia de la revolución mexicana, tomo 19. Mexico City, El Colegio de México.

(1979b): Historia de la revolución mexicana, tomo 20, Mexico City, El Colegio de México.

Warman, A. (1980): We Come to Object: The Peasants of Morelos and the National State, Baltimore, $\mathrm{MD}$.

Whetten, N. (1948): Rural Mexico, Chicago, IL, University of Chicago Press. 